International Conference on Business Research

University of Moratuwa, Moratuwa, Sri Lanka

June 13, 2018, 1-9.

DOI: https://doi.org/10.31705/ICBR.2018.2

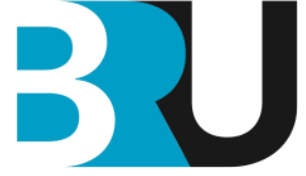

BUSINESS RESEARCH UNIT

FACULTY OF BUSINESS

UNIVERSITY OF MORATUWA

\title{
Exploring opportunities and barriers of community based entrepreneurship within handloom communities in Sri Lanka
}

\author{
Thushari Wanniarachchi ${ }^{*}$, D.G.K. Dissanayake ${ }^{1}$ and Carolyn Downs ${ }^{2}$ \\ ${ }^{1}$ Department of Textile and Clothing Technology, Faculty of Engineering, \\ University of Moratuwa, Sri Lanka \\ ${ }^{2}$ Lancaster University Management School, Lancaster, United Kingdom
}

Community based entrepreneurship (CBE) is an entirely different economic development approach from the traditional manufacturer's base. Also CBE is considered as a promising solution to the livelihood development of small communities in developing countries and acknowledge that it has highest potential in contributing to the economic development as well. Opportunities for CBE within craft traditions have long been recognized as a significant area for development with potential to improve the socio-economic condition of communities. Therefore, this paper attempts to investigate potential openings and barriers for entrepreneurship development in the handloom weaving communities in Sri Lanka. The underpinning research is based on the qualitative exploratory stage of an ongoing study. Based on case study and participatory action research (PAR) approaches, a purposive sampling technique was used to select craftsmen from two handloom communities. The results were analysed taking an emic focus to properly represent findings from participant's terms and viewpoints in line with our PAR approach. Data was then conceptualized, coded and categorized. The findings of the study reveals that there are opportunities for CBE alongside with the ongoing economic processes of the country and also a number of corresponding challenges that need to be addressed for the sustainable development of Sri Lanka through empowering traditional craft communities and direct them with the mainstream market. Currently possessed operational skills, in hand resources and the use of ethical manufacturing process could positively contribute towards this CBE initiation attempt appreciating the group approach with mutual trust among communities. Also CBE has identified key barriers to develop as: lack of entrepreneurial skills, absence of direct market access, shortfall in networking and communication skills, 
structural barriers such as infrastructures and initial support for the capital.

Key words: craftsmen, community, community based entrepreneurship, handloom industry

\section{Introduction}

Poverty alleviation and job creation problems in the developing countries could be addressed using value creation and innovation through local business development. Community Based Entrepreneurship (CBE) is a local business development approach that can be practiced with traditional community manufacturers. Also, it is an alternative social enterprise model, geared towards the pursuit of a community's economic and social development while providing sustainable benefits to individuals and group in both short and long term (Peredo \& Chrisman, 2006). Therefore, CBE is a process through which the community acts entrepreneurially, to create and operate a new enterprise embedded in its existing cultural and social structure (Peredo \& Chrisman, 2006). In addition, CBE attempts to use the entrepreneurship process as a force for economic development by exploiting the resources and assets of the community by adding economic value, creating jobs and keeping scarce resources within the community (Tshikovhi, 2014).

The handloom craft industry in Sri Lanka is one such community based industry that has a potential in contributing to the country's economy (Export Development Board, 2015) while uplifting and sustaining the livelihood of the handloom craftspeople engaged in this work. However, there are no single CBEs created to date for the handloom communities in Sri Lanka. Currently the sector is progressing as a commercial trade, within the local market. Thus, the financial potential of the community based handloom textile industry is well understood, there are many barriers resisting to the growth of this industry through CBE development phenomenon to an economically plausible level. Therefore, there is a huge need to develop the sector together with handloom communities in the country, encouraging CBE in order to meet development goals of the country as well (News.lk, 2018; De Kretser, 2017). Thus, development of such industry in a country will not only gain financial benefits to the economy but also offers social gains such as overall wellbeing of local handloom communities, individual self-esteem, quality of life and community cohesion. As a result, there will be substantial opportunity for sustainable development of their business as well as product innovation to an economically viable level.

Therefore, this study attempts to explore opportunities and barriers for CBE development within handloom communities in Sri Lanka which could be applied to alleviate the chronic poverty. Hence, the study further encourages an entrepreneurial culture, empowers community youth into setting up handloom craft enterprises, reduces growing unemployment problems, and develops sustainable communities within the creative sector while achieving the sustainable development goal of the country. 


\section{Literature review}

CBE is presently distinguished as a feasible alternative for the economic development processes. CBEs are often referred to as 'pro-poor local economic development interventions' pertinent to the entrepreneurship process in developing countries (Parwez, 2017). However, entrepreneurship is defined within this context of impoverished community's development as, 'a force that mobilizes other resources to meet unmet market demand (Stevenson, 1985; Timmons, 1989; Tshikovhi, 2014). In addition, the entrepreneurship process motivates a great potential of self-development strategy for rural community development in declining economies (Korsching \& Allen, 2004).

As Peredo and Chrisman's (2006) exploration shows, CB enterprises are created by community members acting corporately towards its goals. At the same time, they are developing their possessed skills that may contribute to entrepreneurial activities (Tshikovhi, 2014). The fundamental principles of CBE are identified as group approach, mutual trust and motivation towards economic activities encouraged by institutional support (Parwez, 2017). In addition, Bhagavatula, Elfring, Van Tilburg, and Van De Bunt (2010) also recognized some features linked with $\mathrm{CBE}$ activities such as operations, internal problems, effective leadership and support towards establishing a business venture. Moreover, every $\mathrm{CB}$ enterprise tries to achieve the characteristics unique to them such as community skills and resource, multiple social and economic goals once they emerge (Peredo \& Chrisman, 2006). However, according to Tshikovhi, (2014) community entrepreneurs need to develop skills that may contribute to entrepreneurial behaviour such as examines opportunities, solve problems, generating ideas. This process should also include communities assessing opportunities and ideas, using all available sources and resources to evaluate opportunities and ideas, and then planning and preparing the venture thoroughly. This understanding is useful in the contest of Sri Lankan handloom communities as it provides a baseline of capabilities against which to assess the potential for CBE. However, assessment of socio-cultural barriers to CBE is essential in order to do more than develop typography of CBE so that progress towards CBE can be more widely applied in the craft sector.

However, cultural identities also function as a tool for entrepreneurial activities within CBE (Parwez, 2017). In addition, the group effort developed through cultural energy encourages the community to join in one group as a driver working communally towards a CBE development effort (De Beukelaer, 2014). Light and Dana (2013) discussed the challenges faced in the development of CBE in rural areas, emphasizing the lack of continuous support received in business development process from the current markets, service providers, and other entrepreneurs. Further, Parwez (2017) emphasized that the CB entrepreneurial ventures face problems in every step from societal barriers to the market. Moreover, rural communities often have limited opportunities for supporting the progression of CBE with limited opportunities for mentoring, networking, lack of capital and support infrastructure for community development and hence the development of 
CBE (Johnstone \& Lionais, 2004). Therefore, CB entrepreneurs use their assets of community to overcome the obstacles of impoverishment such as financial, professional and labour resources (Johnstone \& Lionais, 2004).

\section{Methodology}

This research has employed the qualitative form of investigation with an holistic approach that emphasizes inductive reasoning to gain insights into the current situation in Sri Lankan handloom sector (Lincoln \& Guba, 1985). A case study and PAR approaches was taken to examine the existing business situation and to recognize the opportunities and barriers for community based entrepreneurship within the handloom craft community in Sri Lanka. PAR allows the researcher to understand the live experience of the community, and to address and problems with the community through an iterative approach. This approach was therefore important in enabling deep understandings of the socio-cultural context that acts as a barrier. This study draws on two case studies as this facilitates cross case analysis and comparison through multiple case study phenomenon (Yin, 2009). Action research is a strategic approach to knowledge creation; incorporating a broad collection of methods and methodological approaches in explicit ways to create new understanding for participants and researchers through solving practical problems (Greenwood \& Levin, 2006). Thus, this study planned two PAR sets facilitated by the Ketso tool kit (Ketso, 2010) to enable involvement with two handloom-weaving communities. This enables us to gain insights into opportunities and barriers to a community based sustainable entrepreneurship in the handloom sector through weavers sharing their livelihood and lived experience. Ketso is toolkit for focus group workshops in a structured way to encourage presenting and sharing ideas of target community groups in a way that facilitates inclusion. Table 1 summarizes the planned case study and PAR activities for the study.

Table 1. Case study \& PAR summary

\begin{tabular}{|c|c|c|}
\hline Community & $\begin{array}{l}\text { Research } \\
\text { strategy }\end{array}$ & Data collection techniques \\
\hline $\begin{array}{l}\text { Thalagune } \\
\text { Traditional Community }\end{array}$ & Case study & $\begin{array}{l}\text { Semi structured interviews by } \\
\text { questionnaires } \\
\text { - With two community leaders } \\
\text { - With two weavers }\end{array}$ \\
\hline $\begin{array}{l}\text { Madampellala } \\
\text { Created Community }\end{array}$ & PAR & $\begin{array}{l}\text { PAR through innovative workshops } \\
\text { facilitated by Ketso toolkit with four } \\
\text { community leaders }\end{array}$ \\
\hline
\end{tabular}

The sample for data collection of this study was selected using a purposive sampling strategy. Base on the relevance of the study and willingness to be developed as entrepreneurs together with the interest to participation of the study, there were 8 interviews conducted with each individual listed in the 
Table 1. All interviews were conducted in Sinhala language and each was more than an hour in length. The interviews were recorded with the consent of the interviewee. The interviews were transcribed and summarized and prepared summary sheets were created (McKevitt, 2007). These were categorized into themes as explained in Yin (2009), and analysed. Ketso interactively allowed four member groups to voice out the opportunities and barriers for CBE. This tool allowed the researcher to make records of the process and the outcomes. Therefore, it did not distract the group interaction in the workshop through taking down notes and photographs were taken of the Ketso kit to record the workshop. Results were captured in a summative manner, categorized into themes and analysed.

\section{Analysis and discussion}

Research was conducted with two different handloom communities in Sri Lanka; Thalagune and Madampellela communities. These two communities are primarily dissimilar to each other from cultural and geographical aspects. Thalagune is the only indigenous traditional weaving community surviving in the country and currently consists of around 35 members of the age range 18 to 70 years of 7 families. Madampellela community is an artificially- created weaving community and is home to a unique handloom cottage industry led by a group of talented artisans. This community was created in the heyday of the handloom industry in the country from the late 50 's by government with the intention of developing the handloom sector in the country. Currently, there are around 2000 families involved into the work force with around 6000 weavers of aged between 18 to 70 years. Both craftsmen and women are engaged in weaving, men fulltime and women while engaging in household work.

Data gathered from the case studies and action research process were categorized into five themes identified from literature considering opportunities and barriers to CBE; results were analysed and summarized as shown in the Table 2.

This study is an initial effort to recognize the existing opportunities and identify barriers for CBE in handloom communities CBEs are built upon the collective skills and resources of the community (Peredo \& Chrisman, 2006). Existing operational skills and available resources of the communities can be considered as a window of opportunity for CBE development and could lead to the community being better connected with the mainstream economy and hence bring social enlistment of the community. Thalagune traditional community is highly experienced with traditional/indigenous designing which is passed down by the generations from the time of serving the king. In addition, they are experts with unique weaving skills in the community. Since Madampellela is a created community, they were inspired with basic design ideas and acquired weaving skills from the training they received at the commencement of the community. However, currently they work with only the basic design knowledge and most of the craftsmen of this community are keen to learn from design ideas from other entrepreneurial designers who come to them for the weaving work. Almost all the craftsmen, in both the 
communities possess their own workshops dedicated to the production process within the own premises with basic machineries and equipment or share resources with neighbour craftsmen (Parwez, 2017). In most cases, the whole family engages in this business while balancing their household work including younger generation, who are being prepared to continue business from their childhood. Thus, both communities are presently well competent to produce any customer request along with their excellent weaving skills and existing resources through ethical production process. Therefore, findings suggest that the outstanding manufacturing capabilities with fundamental design skills could positively impact on a CBE initiation effort and would sustain the benefits within handloom craft communities (Ramachandran, Pant \& Pani, 2012). In addition, their preference for team work with mutual trust and motivation towards CBE initiatives will be a great opportunity for developing this form of entrepreneurial organization.

Entrepreneurial skills such as, business planning, ideas generation, problem solving, creative thinking, pricing, marketing and networks are the most valuable inputs for CBE and are one of the most challenging aspects for the target communities. The study emphasized the skills requirements, which can be practiced in CBE setup while keeping the broader goal as a commercial entity. However, these aspects need to be further addressed for the healthy CBE initiatives to be developed in these communities. In addition, it can be noted that both communities are keen to take a group approach, and prepared to work with mutual trust and have the motivation to develop CEB initiatives.

However, the study reveals several barriers for CBE as well. One of the key barriers identified is market accessibility for the community products. Current marketing channels are not active enough for marketing opportunities to be developed effectively. This is due to a shortfall in prevailing networking for the business and communication and the ability of the community members to develop these networks and skills. These are the key aspects currently preventing CBE success. Also direct customers' involvement in the business is very limited. Indirect sales through retailers and middlemen are the usual practices, whereas for successful CBE the community needs to engage directly with clients. Out of them customary use of intermediaries is the main marketing channel for the community products and as a result middlemen enjoy the large portion of the profit. This is not a healthy situation for CBE within the handloom community. However, the ethical manufacturing practice of the current production process may help to open up new market avenues for eco-minded consumers if the barrier of communication with target markets can be overcome. Therefore, the close coupling of these intersecting customer requirements for such ethical products and a modern design touch would create booming market demand for community handloom products promoting CBE within handloom communities (Bezençon \& Blili, 2010). In addition, the structural barriers such as infrastructure and the lack of support for capital are the other challenges faced by the community members in enhancing CBE phenomenon in this sector. 
International Conference on Business Research

Table 2. Case studies and action researches results analysis

\begin{tabular}{lll}
\hline Challenges & $\begin{array}{l}\text { Thalagune Traditional } \\
\text { Community }\end{array}$ & $\begin{array}{l}\text { Madampellela Created } \\
\text { Community }\end{array}$ \\
\hline
\end{tabular}

1. Operational skills and Resources (Parwez, 2017; Peredo \& Chrisman, 2006; Bhagavatula et al., 2010; Tshikovhi, 2014)
i. Designing skill
Equipped with traditional, indigenous design
Ability in basic
capabilities with cultural
ii. Weaving skill
iii. Skills in offering
customer requirement
iv. Skills for using existing
resources to offered
opportunities
v. Resources
vi. Skills for using available resources to offered opportunities identity
Excellent
Extremely capable
Excellent
designing
Excellent
Highly capable
Excellent
Possess own workshops and basic equipment
Capable in using in hand resources
Ethical manufacturing

\section{Possess own workshops. Basic equipment resources} Capable in using hand
Ethical manufacturing

\begin{tabular}{|c|c|c|}
\hline \multicolumn{3}{|c|}{ 2. Entrepreneurial skill (Tshikovh;, 2014) } \\
\hline $\begin{array}{l}\text { i. Skills in business } \\
\text { planning }\end{array}$ & Less skills & Less skills \\
\hline ii. Skills in generating ideas & Keen in creating ideas & Less skills \\
\hline iii. Problem solving & Posses with certain extent & $\begin{array}{l}\text { Posses with certain } \\
\text { extent }\end{array}$ \\
\hline iv. Creative thinking & Less skills & Less skills \\
\hline $\begin{array}{l}\text { 3. Group approach/ Mutual } \\
\text { trust/ Motivation for CBE } \\
\text { (Parwez, 2017) }\end{array}$ & $\begin{array}{l}\text { Prefer to work as group } \\
\text { with mutual trust. } \\
\text { Very much motivated for } \\
\text { CBE }\end{array}$ & $\begin{array}{l}\text { Encourage in group } \\
\text { approach. Mutual } \\
\text { trust to certain extent. } \\
\text { Some members are } \\
\text { motivated for CBE }\end{array}$ \\
\hline $\begin{array}{l}\text { 4.Support for Capital/ } \\
\text { Infrastructure } \\
\text { (Bhagavatula et al., 2010) }\end{array}$ & Poor & Poor \\
\hline $\begin{array}{l}\text { 5. Networking/ } \\
\text { Communication (Johnstone } \\
\text { \& Lionais, 2004) }\end{array}$ & $\begin{array}{l}\text { Limited with few } \\
\text { customer segments }\end{array}$ & $\begin{array}{l}\text { Limited network } \\
\text { access }\end{array}$ \\
\hline $\begin{array}{l}\text { 6. Marketing \& Market } \\
\text { access (Light \& Dana, 2013; } \\
\text { Parwez, 2017) }\end{array}$ & $\begin{array}{l}\text { Limited market access } \\
\text { with direct customers. } \\
\text { Opportunity to cater for } \\
\text { few international } \\
\text { customers. Indirect sales } \\
\text { through intermediate } \\
\text { parties }\end{array}$ & $\begin{array}{l}\text { Limited market } \\
\text { access. Limited local } \\
\text { direct customer } \\
\text { segment. Indirect } \\
\text { sales through } \\
\text { intermediate parties }\end{array}$ \\
\hline
\end{tabular}




\section{Conclusion and Implications}

The study attempts to explore opportunities \& barriers of CBE to enhance livelihood prospects for handloom communities. It discovers that handloom communities have products that are in demand around the world to sell and that CBE could enable these communities to take charge of their own destiny. Therefore, it is evident that given the conjunction of supportive operational capabilities, basic resources and effective use of them, plus existing ethical manufacturing aspects and the desire for a team approach with mutual trust would encourage CBE within craft communities as a key opportunity. However, reflection of study admits that there are barriers to CBE within the handloom communities due to lack of entrepreneurial skills within the communities and the absence of enterprise education programmes that can be accessed by these people. In addition, customary use of middlemen as the main marketing channel and the lack of direct access to markets due to a shortfall in networking and communication skills, act as significant barriers to the CBE. Encouraging CBE initiatives among craft communities would be possible if systems were created to streamline the marketing channels linking the community sales with direct customer base and under a community brand and if efforts were made to provide enterprise education to likely community groups. CBE activities issues related to infrastructural barriers such as access to transport raw materials and finished goods to market and access to networks could be effectively addressed through formal and informal channels with government support. In addition, policy initiatives such as duty concessions would encourage CBE among members of craft communities in supporting capital investment to enhance the economic and non-economic goals of the craft communities.

\section{References}

Bezençon, V., \& Blili, S. (2010). Ethical products and consumer involvement: what's new? European Journal of Marketing, 44(9/10), 1305-1321.

Bhagavatula, S., Elfring, T., Van Tilburg, A., \& Van De Bunt, G. G. (2010). How social and human capital influence opportunity recognition and resource mobilization in India's handloom industry. Journal of Business Venturing, 25(3), 245-260.

De Beukelaer, C., (2014). Creative industries in "developing" countries: Questioning country classifications in the UNCTAD creative economy reports. Cultural Trends, 23(4), 232-251.

De Kretser, S. (2017, Jan 28). Handlooms to bloom again. Retrieved from http://nation.lk/online/2017/01/28/handlooms-to-bloom-again.html

Export Development Board (EDB). (2015). Export Development Board Trade statistics 2015. Retrieved from http://www.srilankabusiness.com/edb/ trade-statistics.html

Greenwood, D. J., \& Levin, M. (2006). Introduction to action research: Social research for social change. Sage: London.

Johnstone, H., \& Lionais, D. (2004). Depleted communities and community business entrepreneurship: revaluing space through place. Entrepreneurship \& Regional Development, 16(3), 217-233. 
Ketso (2010), Ketso. The hands-on toolkit for creative engagement.

Korsching, P. F., \& Allen, J. C. (2004). Locality based entrepreneurship: a strategy for community economic vitality. Community Development Journal, 39(4), 385-400.

Light, I., \& Dana, L. P. (2013). Boundaries of social capital in entrepreneurship. Entrepreneurship Theory and Practice, 37(3), 603-624.

Lincoln, Y.S. and Guba, E. G. (1985) Naturalistic Inquiry. Sage: Beverly Hills, CA.

McKevitt, C. (2007). Doing Health Anthropology: Research Methods for Community Assessment and Change. Medical Anthropology Quarterly, 21(4), 416-417.

News.lk (2018). Sri Lankan Handlooms access the competitive international market (April 20) retrieved from https://www.news.lk

Parwez, S. (2017). Community-based entrepreneurship: evidences from a retail case study. Journal of Innovation and Entrepreneurship, 6(1), 14.

Peredo, A. M., \& Chrisman, J. J. (2006). Toward a theory of community-based enterprise. Academy of management Review, 31(2), 309-328.

Ramachandran, J., Pant, A., \& Pani, S. K. (2012). Building the BoP producer ecosystem: the evolving engagement of Fabindia with Indian handloom artisans. Journal of Product Innovation Management, 29(1), 33-51.

Stevenson, H. H. (1985). New business ventures and the entrepreneur. Irwin: Homewood, IL.

Timmons, J. A. (1989). The entrepreneurial mind. Brick House: Andover.

Tshikovhi, Ndivhuho, Importance of Sustainable Entrepreneurship Development in Kwamhlanga-Moloto Village, South Africa (October 21, 2014), http://dx.doi.org/10.2139/ssrn.2512811

Yin, R. K. (2009). Case study research: Design and methods. 4th ed. Sage: London. 